Archives of Agriculture and Environmental Science

\title{
Growth, yield and quality of faba bean (Vicia faba L.) in response to sowing date and phosphorus fertilization
}

\author{
Wasima Yasmin ${ }^{1}$, Swapan Kumar Paul ${ }^{1^{*}}$ (D) and Md. Parvez Anwar ${ }^{2}$ \\ ${ }^{1}$ Department of Agronomy, Bangladesh Agricultural University, Mymensingh 2202, BANGLADESH \\ ${ }^{2}$ Agro Innovation Laboratory, Department of Agronomy, Bangladesh Agricultural University, Mymensingh 2202, BANGLADESH \\ Corresponding author's E-mail: skpaul@bau.edu.bd
}

\section{ARTICLE HISTORY}

Received: 17 January 2020

Revised received: 26 February 2020

Accepted: 13 March 2020

\section{Keywords}

Faba bean

Growth

Phosphorus application

Planting time

Seed protein content

Yield components

\section{ABSTRACT}

An experiment was carried out to study the effect of date of sowing and level of phosphorus on the yield, yield components and seed protein content of faba bean (Vicia faba L.) at the Agronomy Field Laboratory, Bangladesh Agricultural University, Mymensingh during November 2018 to March 2019 to study the influence of sowing date and phosphorous fertilization on the growth, yield and quality of faba bean ( $\mathrm{V}$. faba). Three date of sowing viz. 25 November, 5 December, 15 December and five levels of phosphorus viz., 0, 10, 20, 30, $40 \mathrm{~kg}$ P $\mathrm{ha}^{-1}$ were used in this experiment laid out in a randomized complete block design with three replications. At 60 DAS, 25 November sowing fertilized with $40 \mathrm{~kg} \mathrm{P} \mathrm{ha}^{-1}$ showed significant influence on all characters except dry matter production. Early sowing on 25 November produced the tallest plant $(42.95 \mathrm{~cm})$, highest number of branches plant ${ }^{-1}(8.31)$, number of pods plant ${ }^{-1}(49.87), 1000$-seed weight $(97.55 \mathrm{~g})$, seed yield $\left(1.21 \mathrm{t} \mathrm{ha}^{-1}\right)$, stover yield $(1.98 \mathrm{t}$ $\mathrm{ha}^{-1}$ ) and seed protein content (31.54\%) while the corresponding lowest values were recorded from late sowing on 15 December. The crop fertilized with $40 \mathrm{~kg} \mathrm{P} \mathrm{ha}^{-1}$ produced the highest number of branches plant ${ }^{-1}$ (8.33), number of pods plant ${ }^{-1}$ (49.05), 1000-seed weight (97.40 g), seed yield $\left(1.33 \mathrm{t} \mathrm{ha}^{-1}\right)$, stover yield $\left(2.28 \mathrm{t} \mathrm{ha}^{-1}\right)$ and seed protein content $(38.17 \%)$ while control treatment $\left(0 \mathrm{~kg} \mathrm{P} \mathrm{ha}^{-1}\right)$ produced the lowest values of all parameters. In case of interaction, the highest number of pods plant ${ }^{-1}(58.42)$, seed yield $\left(1.59 \mathrm{t} \mathrm{ha}^{-1}\right)$, stover yield $(2.44 \mathrm{t}$ $\mathrm{ha}^{-1}$ ) and protein content in seeds (39.60) were recorded with 25 November sowing fertilized with $40 \mathrm{~kg} \mathrm{P} \mathrm{ha}^{-1}$ whereas the lowest seed yield $\left(0.54 \mathrm{t} \mathrm{ha}^{-1}\right)$, stover yield $\left(1.32 \mathrm{t} \mathrm{ha}^{-1}\right)$ and seed protein content $(25.90 \%)$ were obtained from 15 December sowing along with control treatment. Therefore, early sowing (25 November) with $40 \mathrm{~kg} \mathrm{P} \mathrm{ha}^{-1}$ appears as the promising combination for higher yield and seed protein content of faba bean.

(C)2020 Agriculture and Environmental Science Academy

Citation of this article: Yasmin, W., Paul, S.K. and Anwar, M.P. (2020). Growth, yield and quality of faba bean (Vicia faba L.) in response to sowing date and phosphorus fertilization. Archives of Agriculture and Environmental Science, 5(1): 11-17, https://dx.doi.org/10.26832/24566632.2020.050102

\section{INTRODUCTION}

Faba bean (Vicia faba L.) is popular legume and used worldwide as an important source of protein for human and animal nutrition (Cazzato et al., 2012) and for nitrogen in the biosphere (Rubiales, 2010). Faba bean is grown in some limited locality of Bangladesh and it is locally known as Kalimotor, Baklakalai, Bhograkalai etc. It is commercially grown in Tangail, Gazipur, Manikgang, Faridpur, Rajbari and northern part of Bangladesh.
Faba bean is grown in Bangladesh in winter after the T. aman harvest with minimum tillage or sometimes directly sown in low lying areas as a relay crop when Aman lodges in the field (Biswas, 1988). However no statistical data regarding its area and production are available. Pulse crop covered an area of 0.37 million hectares with the production of 0.39 million tons including very negligible contribution from faba bean (BBS, 2017). Most of the people of Bangladesh fulfill their protein requirement through pulses. Faba bean has been attributed with its certain medicinal 
values and a drug used to treat Parkinson's disease (Brauckmann and Latte, 2010 and Ramírez-Moreno et al., 2015). Determination of optimum date of sowing is important because during growing period of faba bean usually fields are occupied with rice in Bangladesh. Farmers might commonly sow faba bean late because they are wait until their existing crop harvest. Early date of sowing (at the onset of November) significantly increased vegetative growth, seed yield and its quality (Attia et al., 2009) and the greatest values of yield and its components were resulted from the sowing date 25 November (El-Metwally et al., 2013). Late sowing increased field emergence and reduced the number of days to flowering, fresh harvest, reduced green pod length and number of green seeds pod $^{-1}$ and yield. Early sowing of faba bean gave the best values for yield components and seed yield was reported elsewhere (Badr et al., 2013; Abido and Seadh, 2014; Kumar at al., 2020). Phosphorus is a major nutrient, especially for legumes (Kumar et al., 2019). Faba bean may require $P$ fertilizer in the range of 20 to $30 \mathrm{~kg} \mathrm{P} \mathrm{ha}^{-1}$ (FAO, 2000). Significant increases were achieved in faba bean yield and its attributes by increasing phosphorus fertilization rate up to $45-46.5 \mathrm{~kg} \mathrm{P}_{2} \mathrm{O}_{5} \mathrm{fed}^{-1}$ (El-Habbasha et al., 2007). The present study was therefore, undertaken to generate information on the effect of sowing date and phosphorus fertilizer rate on growth, yield and quality of faba bean.

\section{MATERIALS AND METHODS}

Experimental site, soil and climatic conditions

The experiment was conducted at the Agronomy Field Laboratory of Bangladesh Agricultural University, Mymensingh during the period from November 2018 to March 2019. The experimental site belongs to the Old Brahmaputra Floodplain agro-ecological zone (AEZ-9) and is located at $24.75^{\circ} \mathrm{N}$ latitude, $90.50^{\circ} \mathrm{E}$ longitude and an average altitude of $18 \mathrm{~m}$. The experimental field was a medium high land with silt loam with $\mathrm{pH} 6.80$ and low in organic matter content (1.29\%). The experimental area is under the sub-tropical climate. The average monthly temperature $\left({ }^{\circ} \mathrm{C}\right)$, relative humidity $(\%)$, total rainfall $(\mathrm{mm})$ and suns hine (h) prevailing at the experimental site during experimentation are presented in Table 1.

\section{Crop husbandry}

The seeds of faba bean were collected from the local farmers of
Gaibandha district. The experimental land was ploughed with a power tiller and kept open to sunlight. Afterwards the experimental plot was prepared by several ploughing and cross ploughing followed by laddering to break the clods and to level the soil. The weeds and stubbles were removed from the plot. Land preparation was completed on 20 November and was ready for sowing seeds. Seeds were sown in furrow as per treatments of the experiment maintaining $30 \mathrm{~cm} \times 20 \mathrm{~cm}$ spacing with two seeds per hole. The land was fertilized with urea, muriate of potash and gypsum at the rate of 15,60 and $45 \mathrm{~kg}$ $\mathrm{ha}^{-1}$, respectively. The entire amount of urea, muriate of potash (MoP) and gypsum were applied at final land preparation. Phosphorus was applied as TSP as per treatments of the experiment. Weeding and thinning were done at 25 days after sowing (DAS) when the plant attained a height of $8-10 \mathrm{~cm}$. Second weeding were done at 45 DAS when the plant attained about 28 $-30 \mathrm{~cm}$ height. During experimental period, there was no irrigation required. Bean rust was successfully controlled by spraying Copper Oxy Chloride 50WP @ 0.2\% fungicide on 14 February and 21 February, 2019.

\section{Data collection at vegetative stage}

At 60 DAS five plants were randomly selected excluding border rows to record the data on plant height, number of nodules plant $^{-1}$. Chlorophyll content of five fully expanded young leaves from each five plants was measured by using a portable SPAD meter (model SPAD-502, Minolta crop, Ramsey, NJ). To determine the dry matter production, two plants were randomly uprooted from each plot excluding border rows. The total dry weight of plant was taken by using an electric balance after proper drying in an oven at $70^{\circ} \mathrm{C}$ until constant weight was reached.

\section{Data collection at harvest}

Data on plant height, yield components and yield of faba bean were collected at harvest. All data including plant height at harvest, number of branches plant ${ }^{-1}$, Number of pods plant ${ }^{-1}$, Number of seeds pod ${ }^{-1}, 1000$-seed weight except seed yield and stover yield, were collected from five randomly selected plants of each plot, while seed and stover yields data were collected from the whole plot after harvest. Protein content (\%) in seeds was estimated by Micro-Kjeldahl method (AOAC, 1984) at Professor Muhammad Hossain Central Laboratory, Bangladesh Agricultural University, Mymensingh, Bangladesh.

Table 1. Monthly record of air temperature, rainfall, relative humidity and sunshine of the experimental site during the growing season.

\begin{tabular}{|c|c|c|c|c|c|c|c|}
\hline \multirow{2}{*}{ Month } & \multirow{2}{*}{ Year } & \multicolumn{3}{|c|}{ Air temperature $\left({ }^{\circ} \mathrm{C}\right)$} & \multirow{2}{*}{$\begin{array}{l}\text { Rainfall } \\
\text { (mm) }\end{array}$} & \multirow{2}{*}{$\begin{array}{c}\text { Relative } \\
\text { humidity (\%) }\end{array}$} & \multirow{2}{*}{$\begin{array}{l}\text { Sunshine } \\
\text { (hrs) }\end{array}$} \\
\hline & & Maximum & Minimum & Average & & & \\
\hline November & 2018 & 29.30 & 17.40 & 23.40 & 36.20 & 81.70 & 228.9 \\
\hline December & 2018 & 26.00 & 13.50 & 19.80 & 17.70 & 80.20 & 201.3 \\
\hline January & 2019 & 26.28 & 12.16 & 19.07 & 0.00 & 75.39 & 227.2 \\
\hline February & 2019 & 27.03 & 15.55 & 21.29 & 30.00 & 75.86 & 164.8 \\
\hline March & 2019 & 29.82 & 18.95 & 24.38 & 58.60 & 73.03 & 208.2 \\
\hline
\end{tabular}




\section{Harvesting}

When $85 \%$ of the pods turned brown colour, the crop was considered to be matured. The crops were harvested plot- wise from the whole $5 \mathrm{~m}^{2}(2.5 \mathrm{~m} \times 2.0 \mathrm{~m})$ area and then bundled separately, tagged and brought to the threshing floor of Agronomy Field Laboratory. The harvesting date for 25 November, 5 December and 15 December sowing were 14 March, 20 March and 22 March 2019, respectively. The crop bundles were sun dried for 7 days by placing them on the open threshing floor. Seeds were separated from the plants by beating the bundles with bamboo sticks. The separated dried seeds and stover were cleaned and weighed. Seed and stover yields obtained from five sample plants were added with the respective whole plot harvest to get the actual seed and stover yields. Finally seed and stover yields were recorded and converted to $\mathrm{tha}^{-1}$.

\section{Statistical analysis}

Data were compiled and tabulated in proper form for statistical analysis. All the collected data were analyzed following the analysis of variance (ANOVA) technique and mean differences were adjudged by Duncan's Multiple Range Test (DMRT) (Gomez and Gomez, 1984).

\section{RESULTS AND DISCUSSION}

\section{Vegetative characters}

Effect of sowing date had significant effect on different parameters related to growth characters of faba bean (Table 2). Early sowing on 25 November produced higher results on plant height $(26.45 \mathrm{~cm})$, chlorophyll content (37.06) at vegetative stage while the corresponding lowest values were recorded from late sowing on 15 December. Uddin et al. (2017) showed significant effect on plant height due to early sowing date in bean where as Hasanvand et al. (2015) stated that due to delayed sowing chlorophyll content in leaves decreased. Application of $40 \mathrm{~kg} \mathrm{P} \mathrm{ha}^{-1}$ showed higher results on plant height $(24.12 \mathrm{~cm})$, chlorophyll content (36.87), dry matter production plant ${ }^{-1}(0.6833 \mathrm{~g})$ at vegetative stage while the corresponding lowest values were recorded from control treatment (0 kg P ha $\left.{ }^{-1}\right)$. Negasa et al. (2019) stated that plant height increased with increasing level of phosphorus while Mitran et al. (2018) observed that phosphorous plays very crucial role for increasing nodule number in leguminous plants. Root and shoot biomass increased significantly with increase in phosphorus levels, being lower and higher at low and high phosphorus levels, respectively was reported by Mourice and Tryphone (2012). On the other hand, 25 November sowing fertilized with $40 \mathrm{~kg} \mathrm{P} \mathrm{ha}^{-1}$ produced the highest result on vegetative characters of faba bean except dry matter production (Table 3). The highest plant height $(28.10 \mathrm{~cm})$ was obtained at 25 November sowing fertilized with $40 \mathrm{~kg} \mathrm{P} \mathrm{ha}^{-1}$ which was statistically identical at 25 November sowing fertilized with $30 \mathrm{~kg} \mathrm{p}$ $\mathrm{ha}^{-1}, 25$ November sowing fertilized with $20 \mathrm{~kg} \mathrm{P} \mathrm{ha}^{-1}$ and 25 November sowing fertilized with $10 \mathrm{~kg} \mathrm{P} \mathrm{ha}^{-1}$, respectively. The highest Number of nodules plant ${ }^{-1}$ (40.23), chlorophyll content (39.83) at vegetative stage was obtained at 25 November sowing fertilized with $40 \mathrm{~kg} \mathrm{P}^{-1}$ while the lowest number of nodules plant ${ }^{-1}$ (26.14) was obtained at 15 December sowing with $10 \mathrm{~kg} P$ which was at par with 15 December sowing fertilized with control treatment (Table 3).

Table 2. Effect of date of sowing and level of phosphorous on plant height, number of nodules plant ${ }^{-1}$, chlorophyll content and dry matter production at $60 \mathrm{DAS}$ of faba bean.

\begin{tabular}{|c|c|c|c|c|}
\hline Factor and treatments & Plant height $(\mathrm{cm})$ & $\begin{array}{c}\text { Number of nodules } \\
\text { plant }^{-1}\end{array}$ & $\begin{array}{c}\text { Chlorophyll content } \\
\text { (SPAD value) }\end{array}$ & $\begin{array}{c}\text { Dry matter production } \\
\left(\mathrm{g} \mathrm{plant}^{-1}\right)\end{array}$ \\
\hline \multicolumn{5}{|l|}{ Date of sowing } \\
\hline 25-Nov & $26.45 a$ & $33.62 a$ & $37.06 a$ & $0.586 b$ \\
\hline 5-Dec & $21.33 b$ & $34.21 a$ & $35.25 b$ & $0.612 a$ \\
\hline 15-Dec & $17.78 \mathrm{c}$ & $31.98 b$ & $31.89 c$ & $0.550 c$ \\
\hline \multicolumn{5}{|c|}{ Level of phosphorous (kg P ha ${ }^{-1}$ ) } \\
\hline 0 & $19.67 c$ & $30.12 c$ & $32.49 c$ & $0.4933 e$ \\
\hline 10 & $21.61 b$ & $28.23 d$ & $34.69 \mathrm{~b}$ & $0.5367 d$ \\
\hline 20 & $21.92 b$ & $33.18 b$ & $35.10 b$ & $0.5833 c$ \\
\hline 30 & $21.97 b$ & $37.79 a$ & $34.51 \mathrm{~b}$ & $0.6167 b$ \\
\hline 40 & $24.12 \mathrm{a}$ & $37.03 a$ & $36.87 a$ & $0.6833 a$ \\
\hline Level of significance & $* *$ & $* *$ & $* *$ & $* *$ \\
\hline CV (\%) & 7.87 & 5.21 & 2.25 & 5.76 \\
\hline
\end{tabular}

Figures in a column under each factor of treatment having the same letter (s) or without letter do not differ significantly whereas figures with dissimilar letter differ significantly (as per DMRT); ${ }^{* *}=$ Significant at $1 \%$ level of probability. 
Table 3. Interaction effect of date of sowing and level of phosphorus on plant height, number of nodules plant ${ }^{-1}$, chlorophyll content and dry matter production of faba bean at 60 DAS.

\begin{tabular}{|c|c|c|c|c|c|}
\hline \multicolumn{2}{|c|}{ Interaction } & \multirow{2}{*}{$\begin{array}{l}\text { Plant height } \\
(\mathrm{cm})\end{array}$} & \multirow{2}{*}{$\begin{array}{c}\text { Number of } \\
\text { nodules plant }^{-1}\end{array}$} & \multirow{2}{*}{$\begin{array}{l}\text { Chlorophyll } \\
\text { content } \\
\text { (SPAD value) }\end{array}$} & \multirow{2}{*}{$\begin{array}{c}\text { Dry matter } \\
\text { production } \\
\left(\text { g plant }^{-1}\right)\end{array}$} \\
\hline Date of sowing & $\begin{array}{l}\text { Level of phosphorus } \\
\left(\mathrm{kg} \mathrm{P} \mathrm{ha}^{-1}\right)\end{array}$ & & & & \\
\hline \multirow[t]{5}{*}{25 November } & 0 & $22.17 b$ & $32.00 \mathrm{~cd}$ & 34.83ef & 0.500 \\
\hline & 10 & $26.42 a$ & $26.76 \mathrm{e}$ & 35.70 cde & 0.530 \\
\hline & 20 & $27.75 a$ & $34.13 b c$ & $37.47 \mathrm{~b}$ & 0.550 \\
\hline & 30 & $27.83 a$ & $34.99 \mathrm{bc}$ & $37.45 b$ & 0.620 \\
\hline & 40 & $28.10 a$ & $40.23 a$ & $39.83 a$ & 0.730 \\
\hline \multirow[t]{5}{*}{5 December } & 0 & $19.75 \mathrm{bcd}$ & $30.66 \mathrm{~d}$ & $34.04 \mathrm{fg}$ & 0.510 \\
\hline & 10 & $20.92 b c$ & $31.80 \mathrm{~cd}$ & $36.40 \mathrm{bcd}$ & 0.580 \\
\hline & 20 & $20.25 \mathrm{bcd}$ & $33.13 \mathrm{bcd}$ & 35.07def & 0.630 \\
\hline & 30 & $20.33 \mathrm{bcd}$ & $39.47 a$ & $34.04 \mathrm{fg}$ & 0.630 \\
\hline & 40 & $25.42 a$ & $36.01 b$ & $36.69 b c$ & 0.710 \\
\hline \multirow[t]{5}{*}{15 December } & 0 & $17.08 \mathrm{~d}$ & $27.71 \mathrm{e}$ & $28.61 i$ & 0.470 \\
\hline & 10 & $17.50 d$ & $26.14 \mathrm{e}$ & $31.96 h$ & 0.500 \\
\hline & 20 & $17.75 \mathrm{~cd}$ & $32.28 \mathrm{~cd}$ & 32.77gh & 0.570 \\
\hline & 30 & $17.75 \mathrm{~cd}$ & $38.91 a$ & $32.03 \mathrm{~h}$ & 0.600 \\
\hline & 40 & $18.83 \mathrm{~cd}$ & $34.86 b c$ & $34.09 \mathrm{fg}$ & 0.610 \\
\hline Level of significance & & $*$ & $* *$ & $* *$ & NS \\
\hline CV (\%) & & 7.87 & 5.21 & 2.25 & 5.76 \\
\hline
\end{tabular}

In a column, figures with same letter (s) or without letter do not differ significantly whereas figures with dissimilar letter differ significantly (as per DMRT); ${ }^{*}=$ Significant at $5 \%$ level of probability, ${ }^{* *}=$ Significant at $1 \%$ level of probability, NS= Not significant.

Table 4. Effect of date of sowing and level of phosphorous on yield components, yield and seed protein content of faba bean.

\begin{tabular}{|c|c|c|c|c|c|c|c|c|c|c|}
\hline $\begin{array}{l}\text { Factors and } \\
\text { treatments }\end{array}$ & $\begin{array}{l}\text { Plant } \\
\text { height } \\
(\mathrm{cm})\end{array}$ & $\begin{array}{c}\text { Number } \\
\text { of } \\
\text { branches } \\
\text { plant }^{-1}\end{array}$ & $\begin{array}{l}\text { Number } \\
\text { of pods } \\
\text { plant }^{-1}\end{array}$ & $\begin{array}{c}\text { Number of } \\
\text { seeds } \\
\text { pod }^{-1}\end{array}$ & $\begin{array}{l}\text { 1000-seed } \\
\text { weight }(\mathrm{g})\end{array}$ & $\begin{array}{l}\text { Seed } \\
\text { yield } \\
\left(\mathrm{t} \mathrm{ha}^{-1}\right)\end{array}$ & $\begin{array}{l}\text { Stover } \\
\text { yield } \\
\left(\mathrm{t} \mathrm{ha}^{-1}\right)\end{array}$ & $\begin{array}{l}\text { Biological } \\
\text { yield } \\
\left(\mathrm{t} \mathrm{ha}^{-1}\right)\end{array}$ & $\begin{array}{c}\text { Harvest } \\
\text { index } \\
(\%)\end{array}$ & $\begin{array}{c}\text { Seed } \\
\text { protein } \\
\text { content (\%) }\end{array}$ \\
\hline \multicolumn{11}{|l|}{ Date of sowing } \\
\hline 25 November & $42.95 a$ & 8.31a & $49.87 a$ & $3.45 a$ & $97.55 a$ & $1.21 \mathrm{a}$ & $1.98 a$ & $3.19 a$ & $37.61 a$ & $31.54 a$ \\
\hline 5 December & $44.19 a$ & $8.17 a$ & $42.67 \mathrm{~b}$ & $3.19 b$ & $93.04 a$ & $1.07 \mathrm{~b}$ & $1.80 \mathrm{~b}$ & $2.87 \mathrm{~b}$ & $37.18 a$ & $31.48 a$ \\
\hline 15 December & $38.69 b$ & $7.68 b$ & $39.25 c$ & $3.07 \mathrm{~b}$ & $84.84 b$ & $0.78 c$ & $1.74 c$ & $2.52 \mathrm{c}$ & $30.58 b$ & $30.24 b$ \\
\hline \multicolumn{11}{|c|}{ Level of phosphorous (kg P ha-1) } \\
\hline 0 & $37.24 b$ & $7.88 \mathrm{c}$ & $40.29 d$ & $2.99 b$ & $84.24 c$ & $0.646 \mathrm{e}$ & $1.38 \mathrm{e}$ & $2.03 e$ & $31.64 c$ & $28.00 c$ \\
\hline 10 & $41.55 a b$ & $7.88 \mathrm{c}$ & $41.85 c$ & $3.16 b$ & $88.44 b c$ & $0.848 d$ & $1.53 d$ & $2.37 d$ & $35.20 \mathrm{~b}$ & $28.00 c$ \\
\hline 20 & 41.99ab & $8.01 \mathrm{bc}$ & $43.48 b$ & $3.20 b$ & 93.85ab & $1.09 c$ & $1.79 c$ & $2.88 \mathrm{c}$ & $37.42 \mathrm{a}$ & $28.67 c$ \\
\hline 30 & $43.61 a$ & $8.14 a b$ & $44.97 \mathrm{~b}$ & $3.55 a$ & $95.11 a$ & $1.19 \mathrm{~b}$ & $2.21 b$ & $3.40 \mathrm{~b}$ & $34.81 \mathrm{~b}$ & $32.60 \mathrm{~b}$ \\
\hline 40 & $45.31 a$ & $8.33 a$ & $49.05 a$ & $3.26 \mathrm{~b}$ & $97.40 a$ & $1.33 a$ & $2.28 a$ & $3.62 \mathrm{a}$ & $36.56 a$ & $38.17 a$ \\
\hline $\begin{array}{l}\text { Level of } \\
\text { significance }\end{array}$ & $* *$ & $* *$ & $* *$ & $* *$ & $* *$ & $* *$ & $* *$ & $* *$ & $* *$ & $* *$ \\
\hline CV (\%) & 11.26 & 2.81 & 3.63 & 8.63 & 6.58 & 6.79 & 1.69 & 2.01 & 3.12 & 2.86 \\
\hline
\end{tabular}

Figures in a column under each factor of treatment having the same letter (s) or without letter do not differ significantly whereas figures with dissimilar letter differ significantly (as per DMRT); ${ }^{* *}=$ Significant at $1 \%$ level of probability. 
Crop characters, yield components, yield and seed quality

Date of sowing significantly influenced yield components, yield and seed protein content of faba bean (Table 4). Early sowing on 25 November produced higher results on yield components and yield such as plant height $(42.95 \mathrm{~cm})$, number of branches plant $^{-1}$ (8.31), number of pods plant ${ }^{-1}$ (49.87), number of seeds pod $^{-1}$ (3.45), weight of 1000-seed (97.55 g), seed yield $(1.21 \mathrm{t}$ $\left.\mathrm{ha}^{-1}\right)$, stover yield $\left(1.98 \mathrm{t} \mathrm{ha}^{-1}\right)$, biological yield $\left(3.19 \mathrm{t} \mathrm{ha}^{-1}\right)$, harvest index (37.61\%) and seed protein content (31.54\%) of faba bean compared to 5 December and 15 December sowing (Table 4). Early sowing gave the highest number of pods plant ${ }^{-1}$ was reported by Moosavi et al. (2014) and Mozumder et al. (2015). Similar result was reported by Uddin et al. (2017) who reported that 20 November sowing increase yield attributes including 1000-seed weight in French bean. Level of phosphorous also showed significant difference among all parameters related to yield components and yield. Application of $40 \mathrm{~kg} \mathrm{P} \mathrm{ha-1}$ produced higher results on yield components and yield such as plant height $(45.31 \mathrm{~cm})$, number of branches plant ${ }^{-1}$ (8.33), number of pods plant ${ }^{-1}$ (49.05). Zebire and Gelgelo (2019) mentioned that effect of phosphorus significantly increase number of branches plant ${ }^{-1}$ of bean. Application of $39.6 \mathrm{~kg} \mathrm{P} \mathrm{ha}^{-1}$ gave the highest number of pods plant ${ }^{-1}$ in common bean (Phaseolus vulgaris L.) stated by Tesfaye and Balcha (2015). Application of $40 \mathrm{~kg} \mathrm{P} \mathrm{ha}^{-1}$ also produced higher results on weight of 1000 -seed (97.40 g), seed yield (1.33 $\left.\mathrm{t} \mathrm{ha}^{-1}\right)$, stover yield $\left(2.28 \mathrm{t} \mathrm{ha}^{-1}\right)$, biological yield (3.62 $\mathrm{t} \mathrm{ha}^{-1}$ ) and seed protein content $(38.17 \%)$ of faba bean compared to other level of phosphorous. However, $30 \mathrm{~kg} \mathrm{P} \mathrm{ha}^{-1}$ had higher result on number of seeds pod $^{-1}$ (3.55) of faba bean (Table 4). Interaction between 25 November sowing fertilized with $40 \mathrm{~kg} \mathrm{P}^{\mathrm{P}} \mathrm{ha}^{-1}$ produced higher number of pods plant ${ }^{-1}$ (58.42), seed yield (1.59 $\left.\mathrm{t} \mathrm{ha}^{-1}\right)$, stover yield $\left(2.44 \mathrm{tha}^{-1}\right)$, biological yield $\left(4.03 \mathrm{t} \mathrm{ha}^{-1}\right)$ and seed protein content (39.60\%) except plant height, number of branches plant ${ }^{-1}$, 1000-seed weight of faba bean at harvest. Sowing on 25 November fertilized with $30 \mathrm{~kg} \mathrm{P} \mathrm{ha}^{-1}$ had higher result on number of seeds pod ${ }^{-1}$ (4.27) and 25 November sowing fertilized with $20 \mathrm{~kg} \mathrm{P} \mathrm{ha}^{-1}$ had higher result on harvest index (41.62\%) of faba bean. 15 December sowing fertilized with $0 \mathrm{~kg}$ $\mathrm{P}$ ha ${ }^{-1}$ also produced lower results on number of pods plant ${ }^{-1}$ (35.74), seed yield (0.54 $\left.\mathrm{t} \mathrm{ha}^{-1}\right)$, stover yield $\left(1.32 \mathrm{t} \mathrm{ha}^{-1}\right)$, biological yield (1.86 $\mathrm{t} \mathrm{ha}^{-1}$ ), and seed protein content (25.90\%) of faba bean at harvest. 15 December sowing fertilized with $10 \mathrm{~kg} \mathrm{P} \mathrm{ha}^{-1}$ produced the harvest index (28.74\%) of faba bean (Table 5). In case of interaction, the highest seed yield $\left(1.59 \mathrm{t} \mathrm{ha}^{-1}\right)$, and protein content in seeds (39.60) were recorded at 25 November sowing fertilized with $40 \mathrm{~kg} \mathrm{P} \mathrm{ha}^{-1}$ whereas the lowest seed yield $\left(0.54 \mathrm{t} \mathrm{ha}^{-1}\right)$ and seed protein content $(25.90 \%)$ were obtained at 15 December sowing along with control treatment (Table 5 and Figure 1). It can be concluded that early sowing (25 November) along with higher dose of phosphorus fertilization (40 kg P ha ${ }^{-1}$ ) appears as the promising practice for maximizing seed yield and seed protein content of faba bean.

Functional relationship between number of nodules plant ${ }^{-1}$ and seed yield of faba bean

Nodule numbers plant ${ }^{-1}$ and seed yield of faba bean had a positive linear relationship which could be adequately defined by regression equation. The regression equation specifies that increase in number of nodules plant ${ }^{-1}$ would lead to increase in the seed yield of faba bean (Figure 2). The functional relationship was significant at $p \leq 0.01$. The functional relationship can be determined by regression equation $y=-0.8228+0.0554 x$ $\left(R^{2}=0.5422\right)$. The functional relationship revealed that $54 \%$ of the variation in seed yield could be explained from the variation in number of nodules plant ${ }^{-1}$ at vegetative stage of faba bean.

Table 5. Interaction effects of date of sowing and level of phosphorous on yield components, yield and seed protein content of faba bean.

\begin{tabular}{|c|c|c|c|c|c|c|c|c|c|c|c|}
\hline \multicolumn{2}{|l|}{ Interaction } & \multirow{2}{*}{$\begin{array}{c}\text { Plant } \\
\text { height } \\
(\mathrm{cm})\end{array}$} & \multirow{2}{*}{$\begin{array}{c}\text { Number of } \\
\text { branches } \\
\text { plant }^{-1}\end{array}$} & \multirow{2}{*}{$\begin{array}{l}\text { Number } \\
\text { of pods } \\
\text { plant }^{-1}\end{array}$} & \multirow{2}{*}{$\begin{array}{c}\text { Number } \\
\text { of seeds } \\
\text { pod }^{-1}\end{array}$} & \multirow{2}{*}{$\begin{array}{c}1000- \\
\text { seed } \\
\text { weight } \\
\text { (g) }\end{array}$} & \multirow{2}{*}{$\begin{array}{l}\text { Seed } \\
\text { yield } \\
\left(\mathrm{t} \mathrm{ha}^{-1}\right)\end{array}$} & \multirow{2}{*}{$\begin{array}{l}\text { Stover } \\
\text { yield } \\
\left(\mathrm{t} \mathrm{ha}^{-1}\right)\end{array}$} & \multirow{2}{*}{$\begin{array}{c}\text { Biological } \\
\text { yield } \\
\left(\mathrm{t} \mathrm{ha}^{-1}\right)\end{array}$} & \multirow{2}{*}{$\begin{array}{l}\text { Harvest } \\
\text { index } \\
(\%)\end{array}$} & \multirow{2}{*}{$\begin{array}{c}\text { Seed } \\
\text { protein } \\
(\%)\end{array}$} \\
\hline $\begin{array}{l}\text { Date of } \\
\text { sowing }\end{array}$ & $\begin{array}{l}\text { Level } \\
\text { of } P\end{array}$ & & & & & & & & & & \\
\hline \multirow{5}{*}{$\begin{array}{l}25 \\
\text { November }\end{array}$} & 0 & 35.56 & 8.20 & $45.56 \mathrm{~cd}$ & $3.13 b$ & 92.98 & $0.77 \mathrm{~g}$ & 1.46hi & $2.23 \mathrm{j}$ & $34.65 \mathrm{e}$ & 28.70ef \\
\hline & 10 & 43.53 & 8.00 & $45.91 \mathrm{~cd}$ & $3.23 b$ & 98.75 & $0.89 \mathrm{fg}$ & $1.65 \mathrm{~g}$ & $2.54 \mathrm{hi}$ & $35.14 \mathrm{e}$ & 28.70ef \\
\hline & 20 & 43.53 & 8.33 & $48.08 c$ & $3.26 \mathrm{~b}$ & 97.41 & $1.39 \mathrm{~b}$ & $1.95 \mathrm{e}$ & $3.34 d$ & $41.62 a$ & 28.70ef \\
\hline & 30 & 44.74 & 8.40 & $51.36 b$ & $4.27 a$ & 98.34 & $1.41 \mathrm{~b}$ & $2.39 a$ & $3.80 \mathrm{~b}$ & $37.20 \mathrm{~cd}$ & $32.00 \mathrm{~d}$ \\
\hline & 40 & 47.37 & 8.63 & $58.42 a$ & $3.33 b$ & 100.2 & $1.59 a$ & $2.44 a$ & $4.03 a$ & $39.45 b$ & $39.60 a$ \\
\hline \multirow{5}{*}{$\begin{array}{l}5 \\
\text { December }\end{array}$} & 0 & 41.52 & 7.96 & $39.57 \mathrm{fg}$ & $3.06 \mathrm{~b}$ & 80.19 & $0.62 \mathrm{~h}$ & $1.38 \mathrm{j}$ & $2.00 \mathrm{k}$ & $31.13 f$ & $29.40 \mathrm{e}$ \\
\hline & 10 & 42.57 & 8.06 & 40.91efg & $3.20 \mathrm{~b}$ & 86.17 & $1.07 \mathrm{cde}$ & $1.50 \mathrm{~h}$ & $2.57 \mathrm{~h}$ & $41.73 a$ & $28.00 \mathrm{ef}$ \\
\hline & 20 & 44.63 & 8.16 & 42.41ef & $3.20 \mathrm{~b}$ & 97.35 & $1.11 \mathrm{~cd}$ & $1.74 f$ & $2.85 \mathrm{~g}$ & $38.94 b c$ & $29.30 \mathrm{e}$ \\
\hline & 30 & 45.44 & 8.23 & 43.61de & $3.23 b$ & 99.40 & $1.18 \mathrm{c}$ & $2.14 c d$ & $3.32 d$ & 35.54de & $33.60 c$ \\
\hline & 40 & 46.77 & 8.40 & $46.84 c$ & $3.25 b$ & 102.1 & $1.40 \mathrm{~b}$ & $2.24 b$ & $3.64 c$ & $38.58 b c$ & $37.10 \mathrm{~b}$ \\
\hline \multirow{5}{*}{$\begin{array}{l}15 \\
\text { December }\end{array}$} & 0 & 34.65 & 7.50 & $35.74 \mathrm{~h}$ & $2.79 b$ & 79.56 & $0.54 \mathrm{~h}$ & $1.32 \mathrm{k}$ & 1.861 & $29.14 \mathrm{~g}$ & $25.90 \mathrm{~g}$ \\
\hline & 10 & 38.56 & 7.60 & $38.73 \mathrm{~g}$ & $3.06 \mathrm{~b}$ & 80.41 & $0.58 \mathrm{~h}$ & $1.44 \mathrm{i}$ & $2.02 \mathrm{k}$ & $28.74 \mathrm{~g}$ & $27.30 f g$ \\
\hline & 20 & 37.82 & 7.53 & $39.94 \mathrm{fg}$ & $3.13 b$ & 86.79 & $0.78 \mathrm{~g}$ & $1.68 \mathrm{~g}$ & $2.46 i$ & $31.69 f$ & 28.00ef \\
\hline & 30 & 40.65 & 7.80 & $39.94 \mathrm{fg}$ & $3.16 \mathrm{~b}$ & 87.59 & 0.97 ef & $2.10 d$ & $3.07 f$ & $31.69 f$ & $32.20 \mathrm{~cd}$ \\
\hline & 40 & 41.79 & 7.96 & 41.91ef & $3.20 \mathrm{~b}$ & 89.87 & 1.01def & $2.18 c$ & $3.19 \mathrm{e}$ & $31.65 f$ & $37.80 \mathrm{~b}$ \\
\hline $\begin{array}{l}\text { Level of } \\
\text { significance }\end{array}$ & & NS & NS & $* *$ & $*$ & NS & $* *$ & $* *$ & $* *$ & $* *$ & $* *$ \\
\hline CV (\%) & & 11.26 & 2.81 & 3.63 & 8.63 & 6.58 & 6.79 & 1.69 & 2.01 & 3.12 & 2.86 \\
\hline
\end{tabular}

In a column, figures with same letter (s) or without letter do not differ significantly whereas figures with dissimilar letter differ significantly (as per DMRT). ${ }^{*}=$ Significant at $5 \%$ level of probability, ${ }^{* *}=$ Significant at $1 \%$ level of probability, NS $=$ Not significant. 


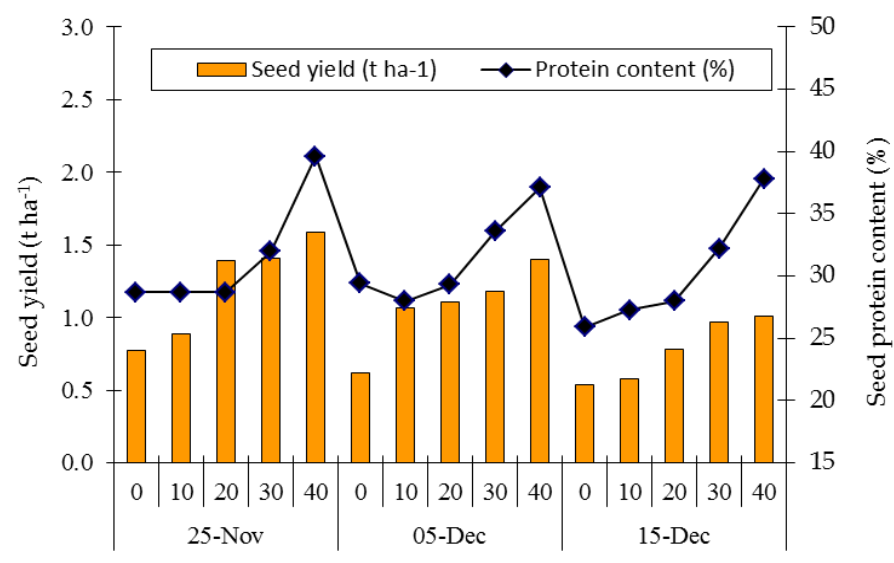

Interaction between date of sowing and level of phosphorous

Figure 1. Interaction effect of date of sowing and level of phosphorous on seed yield and seed protein content of faba bean.

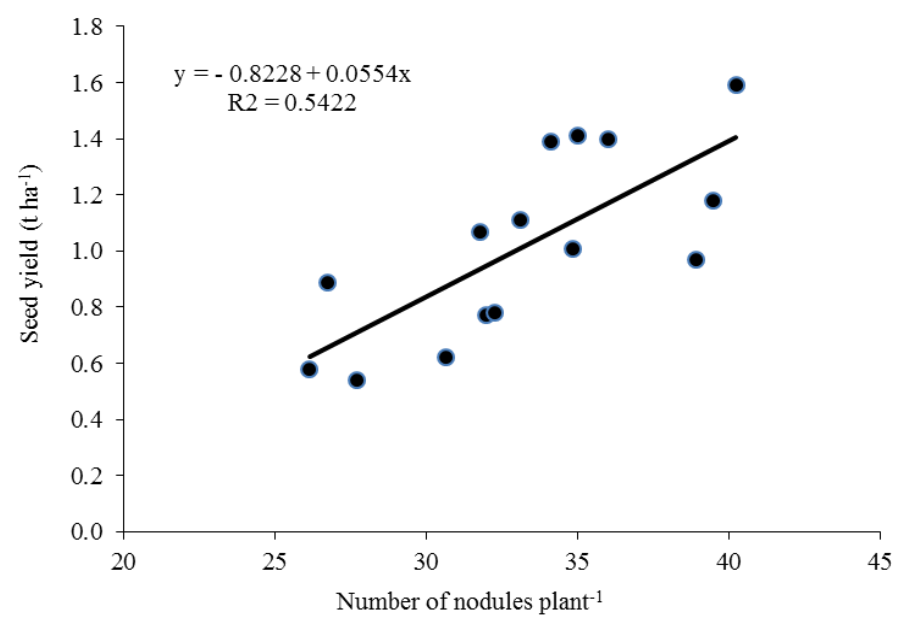

Figure 2. Functional relationship between number of nodules plant ${ }^{-1}$ and seed yield of faba bean.

\section{Conclusion}

Early sowing on 25 November produced the tallest plant, highest number of branches plant ${ }^{-1}$, number of pods plant ${ }^{-1}$, 1000 -seed weight, seed yield, stover yield and seed protein content while the corresponding lowest values were recorded from late sowing on 15 December. The crop fertilized with 40 $\mathrm{kg} \mathrm{P} \mathrm{ha}{ }^{-1}$ produced the highest number of branches plant ${ }^{-1}$, number of pods plant $^{-1}, 1000$-seed weight, seed yield stover yield and seed protein content. The highest number of pods plant $^{-1}$, seed yield, stover yield and protein content in seeds were recorded with 25 November sowing fertilized with $40 \mathrm{~kg} P$ $\mathrm{ha}^{-1}$ whereas the lowest seed yield, stover yield and seed protein content were obtained from 15 December sowing along with control treatment. From the results of the study it can be concluded that 25 November sowing fertilized with $40 \mathrm{~kg} \mathrm{P} \mathrm{ha}^{-1}$ appears as the promising combination for higher seed yield and protein content of faba bean

\section{ACKNOWLEDGEMENTS}

The financial assistance of Bangladesh Agricultural University Research System (BAURES) (2018/333/BAU) to conduct the research project is thankfully acknowledged.
Open Access: This is an open access article distributed under the terms of the Creative Commons Attribution 4.0 License, which permits unrestricted use, distribution, and reproduction in any medium, provided the original author(s) if the sources are credited.

\section{REFERENCES}

Abido, W.A.E. and Seadh, S.E. (2014). Rate of variations between field bean cultivars due to sowing dates and foliar spraying treatments. Science International, 2(1): 1-12.

Attia, A.N., Seadh, S.E., El-Emery, M.I. and El-Khairy, R.M.H. (2009). Effect of planting dates and seed size on productivity and quality of some faba bean cultivars. Journal of Agricultural Sciences, 34: 11311-11324.

Badr, E.A., Asal, M.W. and Amin, G.A. (2013). Effect of sowing dates and bio fertilizer on growth attributes, yield and its components of two faba bean (Vicia faba L.) cultivars. World Applied Sciences Journal, 28(4): 494-498.

BBS (Bangladesh Bureau of Statistics) (2017). Yearbook of Agricultural statistics. BBS, Ministry of Planning, Government of the People's Republic of Statistics and Informatics Division, Bangladesh, Dhaka. pp. 101.

Biswas, B.K. (1988). Genotype and environment interaction in faba bean. M.Sc. Thesis, Department of Genetics and Plant Breeding, Bangladesh Agricultural University. pp. 1-40.

Brauckmann, B.M. and Latte, K.P. (2010). L-Dopa deriving from the beans of Vicia faba and Mucuna pruriens as a remedy for the treatment of Parkinson's disease. Swiss Journal of Integrative Medicine, 22: 292-300.

Cazzato, E., Tufarelli, V., Ceci, E., Stellacci, A.M. and Laudadio, V (2012). Quality, yield and nitrogen fixation of faba bean seeds as affected by sulphur fertilization. Acta Agriculturae Scandinavica, Soil and Plant Science, 62: 732-738.

El-Habbasha, S.F., Hozayn, M. and Khalafallah, M.A. (2007). Integration effect between phosphorus levels and bio-fertilizers on quality and quantity yield of faba bean (Vicia faba $\mathrm{L}$ ) in newly cultivated sandy soils. Research Journal of Agriculture and Biological Sciences, 3(6): 966-971.

El-Metwally, I.M., El-Shahawy, T.A. and Ahmed, M.A. (2013). Effect of sowing dates and some broomrape control treatments on faba bean growth and yield. Journal of Applied Sciences Research, 9: 197- 204.

FAO- IFA (2000). Fertilizers and Their Use. $4^{\text {th }}$ edition, FAO, Rome.

Gomez, K.A. and Gomez, A.A. (1984). Statistical Procedures for Agricultural Research $2^{\text {nd }}$ Edition., A Willy Inter- Science Publications, John and Sons, New York. pp. 202-215.

Hasanvand, H., Siadat, S.A., Moraditelavat, M.R., Mousavi, S.H. and Karaminejad, A. (2015). The effect of different sowing dates on physiological characteristics of faba bean (Vicia faba L.) varieties in Khouzestan Ramin. Iranian Journal of Pulses Research, 6: 47-58.

Mitran, T., Meena, R.S., Lal, R., Layek, J., Kumar, S. and Datta, R. (2018). Role of soil phosphorus on legume production. Legumes for Soil Health and Sustainable Management, 487-510.

Moosavi, S.G., Seghatoleslami, M.J. and Delarami, M.R. (2014). Effect of sowing date and plant density on yield and yield components of lentil (Lens culinaris cv. Sistan). Annual Research and Review in Biology, 4(1): 296-305.

Mourice, S.K. and Tryphone, G.M. (2012). Evaluation of common bean (Phaseolus vulgaris L.) genotypes for adaptation to low phosphorus. International Scholary Research Network, 20129.

Mozumder, S.N., Moniruzzaman, M., Islam, M.R. and Alam, S.N. (2003). Effect of planting time and spacing on the yield performance of bush bean (Phaseolus vulgaris L.) in the eastern hilly area of Bangladesh. Legume Research, 26(4): 242-247.

Negasa, G., Bedadi, B. and Abera, T. (2019). Influence of phosphorus fertilizer rates on yield and yield components of faba bean (Vicia faba L.) varieties in Lemu Bilbilo district of Arsi zone, southeastern Ethiopia. International Journal of Plant \& Soil Science, 28(3): 1-11.

Ramírez-Moreno, J.M., Salguero, B.I., Romaskevych, O. and Duran-Herrera, M.C. (2015). Broad Bean (Vicia faba) consumption and Parkinson's disease: natural source of L-dopa to consider. Neurología, 30:375-376.

Rubiales, D. (2010). Faba beans in sustainable agriculture. Field Crops Research, 115: 201-202.

Tesfaye, T. and Balcha, A. (2015). Effect of Phosphorus application and varieties on grain yield and yield components of common bean (Phaseolus vulgaris L.). American Journal of Plant Nutrition and Fertilization Technology, 5 (3): 79-84. 
Uddin, F.M.J., Kashem, M.A., Islam, A.K.M.M. and Sarkar, M.A.R. (2017). Optimizing sowing date for french bean varieties under Bangladesh condition. Annual Research \& Review in Biology, 21(3): 1-7.

Kumar, V., Singh, J. and Kumar, P. (2019). Heavy metals accumulation in crop plants: Sources, response mechanisms, stress tolerance and their effects. In: Contaminants in Agriculture and Environment: Health Risks and Remediation, 1, pp. 38, https://doi.org/10.26832/AESA-2019-CAE-0161-04 Kumar, V., Kumar, P. and Khan, A. (2020). Optimization of PGPR and silicon fertilization using response surface methodology for enhanced growth, yield and biochemical parameters of French bean (Phaseolus vulgaris L.) under saline stress. Biocatalysis and Agricultural Biotechnology, 23: 101463, https://doi.org/10.1016/j.bcab.2019.101463

Zebire, D.A. and Gelgelo, S. (2019). Effect of phosphorus fertilizer levels on growth and yield of haricot bean (Phaseolus vulgaris L.) in south Ommo zone, Ethiopia. Agricultural Science Digest, 39(1): 55-58. 